Akad. Wiss. Wien, Math.-Naturwiss. Kl. III:69-92.

Henley, R.W. 1992. Two years of change in Florida's tissue culture industry. Foliage News, IFAS, Univ. of Florida. 16(3)1-6.

Janick, J. (ed.). 1989. Classic papers in horticultural science. Prentice Hall, Englewood Cliffs, N.J.

Jones, J.B. 1987. Commercial plant tissue culture in the United States. Acta Hort. 212:639-643.

Jones, J.B. and C.J. Sluis. 1991. Marketing of micropropagated plants, p. 141154. In: P.C. Debergh and R.H. Zimmerman (eds.). Micropropagation. Kluwer Academic Publ., Dordrecht, Netherlands.

Morel, G.M. 1960. Producing virus-free cymbidiums. Amer. Orchid Soc. Bul. 29:495-497.

Murashige, T. and L.-C. Huang. 1987. Cloning plants by tissue culture: Early years, current status and future prospects. Acta Hort. 212:639-643.

Pierik, R.L.M. 1991. Commercial aspects of micropropagation, p. 141-153. In: J. Prokash and R.L.M. Pierik (eds.). Horticulture-New technologies and application. Kluwer Academic Publ., Netherlands.

Reuveni, O., S. Golubowicz, and Y. Israeli. 1993. Factors influencing the occurrence of somaclonal variations in micropropagated bananas. Acta Hort. 336:357-364.

Standaert-de Metsenaere, R.E.A. 1991. Economic considerations, p. 123-140. In: P.C. Debergh and R.H. Zimmerman (eds.). Micropropagation. Kluwer Academic Publ., Dordrecht, Netherlands.

Zimmerman, R.H. and J.B. Jones. 1991. Commercial micropropagation in North America, p. 173-179. In: P.C. Debergh and R.H. Zimmerman (eds.). Micropropagation. Kluwer Academic Publ., Dordrecht, Netherlands.

\title{
Hormones and Horticulture
}

\author{
Norman E. Looney \\ Pacific Agri-Food Research Centre, Agricülture and Agri-Food Canada, Summerland, B.C. V0H 1Z0, Canada
}

In their book Hormones and Horticulture, Avery and Johnson (1947) confidently stated that

\begin{abstract}
"A chemical revolution is sweeping through the agricultural world. It is unrivalled by any of the previous great advances in agriculture and, perhaps, by most advances in the biological field. For the first time man can change the pattern of growth and development of plants, can retard growth here and speed it there. The growth-controlling hormones...now in use are but crude beginnings."
\end{abstract}

Indeed, by the mid-1940s it was clear to most research horticulturists in North America that if they were to continue to be considered relevant within their chosen field of science they had better climb on board the hormones and horticulture wagon. It reminds me of the present belief (fear plus trust!) that molecular genetics is "where it's at," and even "where it will be" for decades to come.

Still, spectacular progress was made over a relatively few decades in understanding the important capabilities of endogenous "hormones", and demonstrating that plant growth and development could be profoundly influenced by the "plant growth regulators" (PGRs) developed by a confident and forward-looking agricultural chemicals industry. (Since many of these chemicals do not influence growth I prefer "plant bioregulators" and will use PBRs from here on.)

My task is to chart the ascent of the hormones and horticulture era and to reflect on its "staying power." My approach will be to deal with four successive 20- to 40-year "phases" starting in the 19th century. I will present bibliometric data from several sources to support the hypothesis that research on endogenous hormones in horticultural plants and PBR usage in horticultural technology (hormones and horticulture, for short) continues to receive major attention.

Even in the 1990s, when the tools of molecular biology are being applied to answering fundamental questions about hormone action, there is optimism that a new understanding of the relationship between hormones and gene expression will lead to the development of new plant materials and new chemical tools for use in horticulture.

\section{PHASE I. EARLY INVESTIGATIONS 1880-1920}

The discoveries and observations that founded this field of research occurred during the last quarter of the 19th century. Good work in a

Received for publication 4 Mar. 1997. Accepted for publication 4 Apr. 1997. I wish to thank Ms. Peggy Watson, Summerland Research Centre librarian, for her generous assistance with the bibliometric analysis. The cost of publishing this paper was defrayed in part by the payment of page charges. Under postal regulations, this paper therefore must be hereby marked advertisement solely to indicate this fact. relatively few laboratories gave credibility to the concept that endogenous chemical "regulators" might control important aspects of plant growth and development.

Darwin and Darwin (1880) reported their classic experiments on phototropism and geotropism that predicted the existence of a chemical transmitter or messenger. The idea of correlative growth of plant organs was introduced at about the same time by Julius Sachs (e.g., 1880). Sachs' contributions were of immense importance in that he was the first to apply the laws of causality to organ development. $\mathrm{He}$ assumed the existence of root-forming, flower-forming, and other substances that moved in different directions in the plant. However, Boysen-Jensen $(1911,1913)$ appears to have been the first to actually demonstrate, by grafting, that the phototropic stimulus was "chemical" in nature.

The term "hormone" was introduced into animal physiology to denote a substance produced in one part of the organism and transferred to another part to influence a specific physiological process. These specifications, of course, do not always apply in plant systems. Nonetheless, the term hormone was used in plant biology as early as 1910 (Fitting, 1910) and given legitimacy in later reviews such as that by J.S. Huxley (1935). Went and Thimann (1937) confirmed that the "hormone concept" was applicable to plants. The term "phytohormone" was preferred by these latter authors.

\section{PHASE II. THE DISCOVERY AND PROMISE OF AUXIN 1920-1945}

The "modern age" of phytohormones began in the 1920 s when F.W. Went (1928) isolated an active substance from oat coleoptile tips that later proved to be indoleacetic acid (IAA) or auxin. Researchers worldwide joined the chase and by 1937 Went and Thimann noted that the bibliography to their book Phytohormones, published in 1937, included 77 papers published in 1936!

"The field of plant hormones is perhaps now at the stage of its most rapid development. The number of facts is becoming so large, and their distribution through the literature so scattered that there is danger of losing sight of the general trend" (Went and Thimann, 1937).

Furthermore, as suggested by another notable quote, they felt that most of what needed to be known about this subject had already been discovered!

"This survey of the rapidly developing field of phytohormones shows that many problems have been solved and few really important points are still subjects of disagreement." 
One particularly notable achievement during the 1930s was the discovery that chemicals very different in structure from IAA could exhibit auxin-like activity in systems such as the rooting of cuttings (e.g., Zimmerman and Wilcoxon, 1935) and by the mid-1940s several horticultural (and agronomic) uses of synthetic auxins were well established. These included 1) rooting of cuttings; 2) induction of parthenocarpic fruit set of tomato; 3) controlling preharvest drop of apples; 4) reducing fruit set of apple (fruit thinning); and 5) selective killing of broad-leafed weeds.

\section{Rooting}

A key paper in the development of auxinic treatments to stimulate rooting of woody cuttings was that by W.C. Cooper (1935), who used IAA in lanolin paste to stimulate rooting of several woody species (Cooper's early papers were in Plant Physiology, Botanical Gazette, and Science; later on they were mainly in the Proceedings of the American Society for Horticultural Science.)

Within a very few years there was a wealth of evidence that a host of synthetic auxins could be used to stimulate rooting of cuttings and this had become a standard practice in plant propagation. In 1947, Avery and Johnson cited more than 100 papers dealing with hormonal treatments to stimulate rooting of cuttings. Today it is difficult to imagine pomology and ornamental horticulture without the rooting technology based on these very early reports.

\section{Fruit set}

F.G. Gustafson (1936) was the first to demonstrate that a specific chemical could be used to achieve fruit set and full organ development without pollination. F.S. Howlett (1940) is credited with developing PBR technology for greenhouse tomato production and by the end of the 1940s hundreds of studies had been reported dealing with the improvement of fruit set of all kinds of vegetables, berries and tree fruits.

\section{Abscission control}

Reducing preharvest drop of apples with materials like naphthalene acetic acid (NAA) or its potassium salt arose directly from the observation by LaRue (1936) that auxinic chemicals delayed the abscission of Coleus leaves. Gardner and Marth (1937) observed the same for holly berries and it was Gardner et al. $(1939,1940)$ who developed this technology for apples. Avery and Johnson (1947) cited 69 references to the chemical control of abscission, mainly of apples.

\section{Fruit thinning}

Another early application of hormones to tree fruit horticulture was the use of NAA or its amide salt to reduce fruit set of apple. This grew out of work where the chemical of choice was dinitro-ortho-crysylate (DNOC), a caustic and nonselective weed killer applied during the flowering period. NAA was tried by Schneider and Enzie (1944) and within a few years NAA applied after the bloom period to reduce fruit set (even of pollinated flowers) was an established practice.

\section{Selective herbicides}

By the start of the 1940s, it was known that many synthetic chemicals exhibited activity in Went's Avena coleoptile bioassay. Within a few years of the discovery by Zimmerman and Hitchcock (1942) that certain substituted phenoxy compounds were extraordinarily active auxins, selective and relatively safe herbicides (certainly safer that those existing at the time) were developed for crop production. Active ingredient concentrations as low as $50-100 \mathrm{ppm}$ were sufficient to kill many weeds.

Both in terms of economic value and the potential for yield improvement the importance of this discovery is almost impossible to overestimate. Herbicides soon became essential for the economic production of many agronomic crops. Indeed, a whole generation of plant physiologists specializing in the development and use of herbicides can think of 1941 or 1942 as their "birthday."

\section{PHASE III. THE GOLDEN AGE OF PRODUCT AND TECHNOLOGY DEVELOPMENT 1950-1980}

In an effort to illustrate the dynamics of horticultural crop-related research on plant bioregulators during the postwar period, I counted the relevant citations in Horticultural Abstracts that dealt with apple, tomato, and chrysanthemum from 1946 to 1990 (Fig. 1). Each point is the annual average over a 5-year period.

There was a relatively steady increase in activity until about 1980 for apples, 1975 for tomatoes and 1970 for chrysanthemums, after which research activity either levelled off or declined. This analysis seems to support the view that PBR research on these crops was indeed more "fashionable" in 1968 than it is today, although it also indicates that there is very substantial activity involving apple and tomato right up to the present day.

There are probably many explanations for this period of rapid growth in applied PBR research and development. It has been argued that the success during WW II of converting past successes in basic science into important tools for the War effort (e.g., radar, sonar, nuclear energy) changed the mind-set of the public at large. No longer was "science for science's sake" seen as acceptable. Suddenly there had to be a practical benefit to society. Research into plant biology was now expected to result in practical gains in horticulture, agronomy and forestry.

During a period lasting at least three decades, most western democracies experienced improvements in production efficiency (which meant lower prices to consumers), product availability, and quality (size, appearance, and freedom from pest and disease damage) that were unprecedented. Furthermore, concerns that these gains might be difficult to sustain or that some of the new-found tools could prove faulty, even hazardous to the environment, were practically nonexistent.

With specific regard to plant bioregulators, the early successes in turning new knowledge about auxins into useful horticultural and agricultural technologies led many to believe that this rate of progress could be sustained indefinitely. Chemical companies established large and well-funded research teams; the focus, then and now, was on the development of chemical tools of value to major markets. Bioregulators

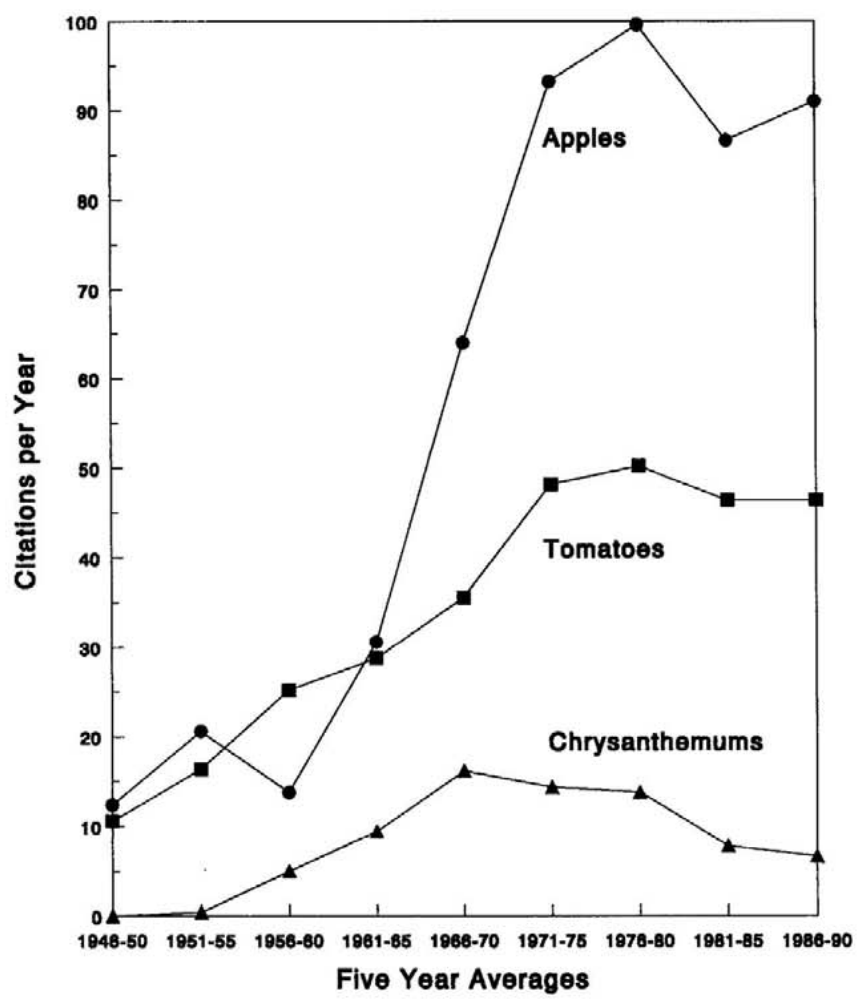

Fig. 1. Citations per year in Horticultural Abstracts, averaged over nine consecutive 5-year periods, that deal specifically with PBR research on apple, tomato, and chrysanthemum. 
and selective herbicides for corn, cotton, soybeans, etc., promised the greatest financial rewards. Interestingly, horticulture, despite the high value of many commodities, was never considered a high priority area by the chemical industries searching for new bioregulators.

Still, this golden age of product and technology development saw horticultural scientists (mostly employed in the public sector) develop ever more sophisticated PBR-based practices to improve the efficiency of crop production. Other scientists creatively combined new knowledge about natural plant growth regulation (public sector research) with new chemicals being developed for major agronomic and plantation crops (private sector research and development) to introduce a steady flow of major improvements to horticultural and agronomic crop production systems.

There were many examples of this synergy. New tissue-culturebased propagation techniques would arise from the pioneering work of F.C. Steward and others (e.g., Nickell, 1958; Steward and Simmonds, 1954), but not until synthetic cytokinins became commonly available. Studies on factors controlling fruit set of apple led to new fruitlet thinning technology when carbaryl, introduced by Union Carbide as a broad-spectrum insecticide, was fortuitously used in an experimental orchard (Batjer and Westwood, 1960).

During this period gibberellins were rediscovered by western scientists (see Stowe and Yamaki, 1957) and a host of novel applications in horticultural crop production systems were reported. They proved useful for increasing berry weight of seedless grapes, breaking dormancy of rhubarb crowns lifted for forcing, delaying rind senescence of citrus fruits, and as a therapeutic treatment for a serious virus disease of sour cherry, to name but a few important uses in horticulture. Growth retardants that reduced shoot elongation and promoted flowering revolutionized floriculture and proved very useful in tree fruit horticulture. Ethylene, known since the 1930 s, became fully recognized as an important endogenous hormone with very intricate and interesting biosynthetic pathways (see Pratt and Goeschl, 1969). Ethephon, a bioregulator that generated ethylene gas in treated tissues found ready application in a very wide range of horticultural and plantation crops. A potent inhibitor of ethylene biosynthesis, aminoethoxyvinylglycine(AVG), was discovered(Owens etal., 1971).

Other important advances in our understanding of endogenous hormone chemistry and physiology were being reported. Abscisic acid was discovered (Ohkuma et al., 1963) and its role as an endogenous regulator defined (see Addicot and Lyon, 1969).

Cytokinins were formally recognized as an important class of endogenous hormones (Letham, 1967; Miller et al., 1955; Skoog and Armstrong, 1970).

Thus, throughout this "golden age" we saw excellent progress in understanding the complexities of the natural chemical control systems in plants and in the development of PBR technology of value to horticultural industry. Interestingly, Fritz Went (1940) quite accurately predicted this situation (although I doubt that many would now totally agree with his utopian view of the politics of American science).

"In conclusion, I want only to mention that increase in our knowledge concerning the basic principles of plant growth inevitably leads, and in fact has led, towards practical applications in agriculture and horticulture. No better example of the application of so-called pure research to practical problems could be quoted than this on plant hormones, which means in other words, that a distinction between pure and applied research is highly artificial, and should be dropped, as it is being dropped here in America."

\section{PHASE IV. 1980- ONGOING RESEARCH IN AN ERA OF PUBLIC SKEPTICISM-THE ASCENDANCY OF MOLECULAR GENETICS}

There are nearly as many theories and opinions as there have been commentators about the roots of public discontent about agricultural chemicals. Sometime in the late 1970 s it became clear that public opinion was highly supportive of efforts to reduce reliance on pesticides and herbicides in agricultural production systems. At the same time, public sector funding of research aimed at identifying potential long-term health hazards of various agricultural chemicals was growing rapidly. Pesticide residues were loudly touted as cancer-causing agents even though the evidence was seldom convincing.

At the same time, overproduction of many food crops was being blamed for low returns to producers. A prevailing argument was that "production efficiency" research was much less important to society than "product quality", "sustainability" and "resource management" research. Inevitably, we saw a progressive decline in support for research related to all facets of agricultural chemistry, including, of course, plant bioregulators. With the "Alar Episode" of the late 1980s we saw the full manifestation of public mistrust of agricultural chemicals in North America. This was followed by an even steeper decline in support for PBR research and development.

However, a precipitous decline in research reports on PBR topics has yet to occur. National and international horticultural science journals have about as many papers featuring PBR research and development in the 1990s as was the case during the 1970s.

Furthermore, despite the acknowledged hostile public opinion about the use of "hormones" in food production systems, the reality is that most of the PBR products and procedures developed during the past 50 years are still in use around the world. Many are still being refined and adapted for specific regions. In general, they are being used in a safe and sustainable manner to maintain or improve competitiveness in a world increasingly free of trade barriers.

One measure of the continuing interest in plant bioregulation research is the number of papers abstracted by Plant Growth Regulator Abstracts. This publication, dating from 1975, deals with research reports on plant hormones and PBR usage across all crop species. Fundamental work involving noncrop plant species is also considered. The general trend of new entries from 1975 to 1993 (Fig. 2) shows a steady increase from 2000 in 1975 to 2500 in 1994.

Similarly, simply counting the pages of the review articles specifically devoted to hormone and PBR topics in each volume of the Annual Review of Plant Physiology and Plant Molecular Biology provides a measure of the ongoing interest in this area. As the total number of pages in these books has increased from about 400 in 1950 to nearly 700 pages in recent years (reflecting the proliferation of new subject matter areas), a remarkably constant 100 pages per year have been

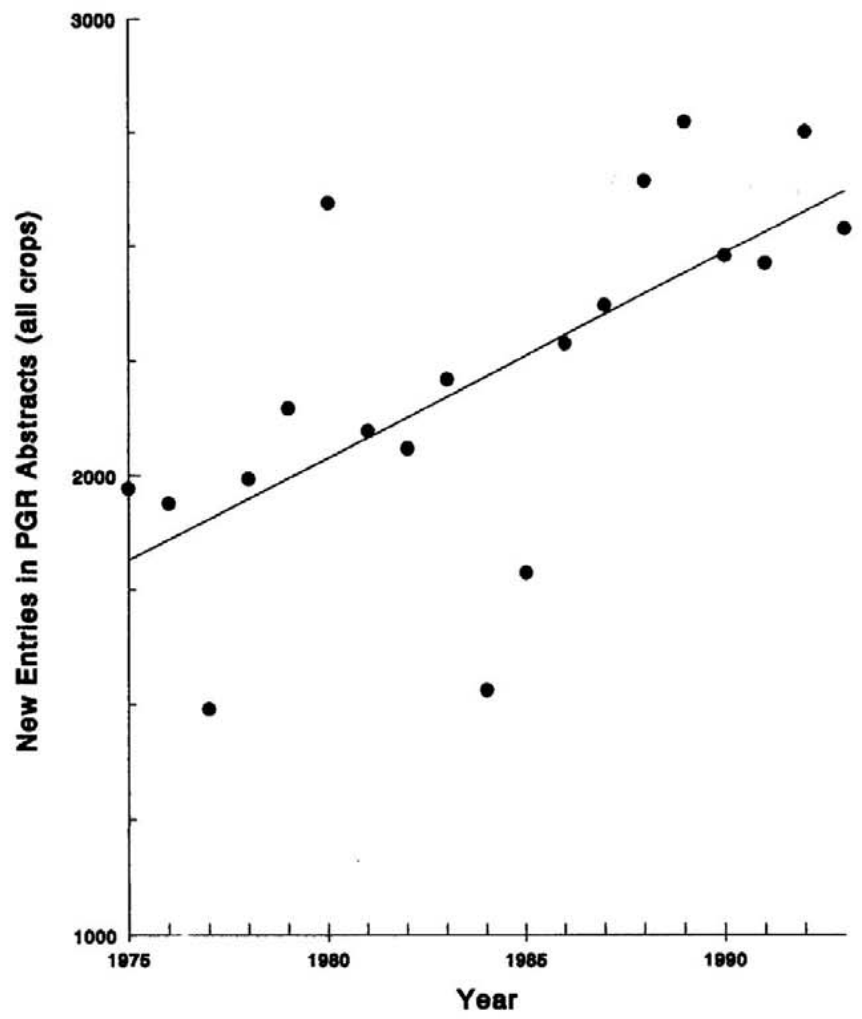

Fig. 2. New papers abstracted by Plant Growth Regulator Abstracts over the period of 1975-93. 


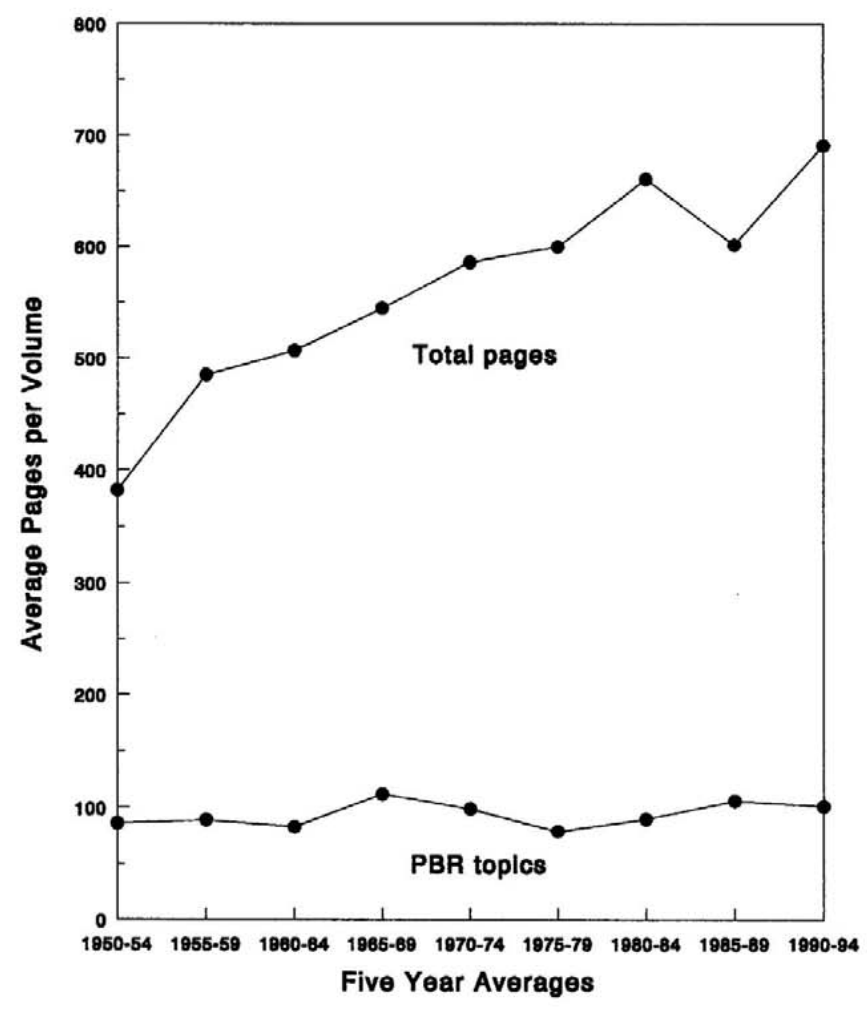

Fig. 3. Average pages per volume of the Annual Review of Plant Physiology devoted to plant bioregulation topics. Each point is the average for a 5-year period.

devoted to hormone and PBR topics throughout the 45 year history of this journal (Fig. 3).

Still, despite these indications of the "staying power" of traditional hormone research and associated PBR technology development, it is increasingly clear that future advances in the bioregulation of horticultural crop plants will arise primarily from the study of plant molecular genetics. Future PBRs will arise from a more detailed knowledge of very specific natural regulatory mechanisms or perhaps be associated with the introduction of transgenic plants with specific advantages and limitations. Clearly, the time when chemical companies screened chemicals for PBR activity (usually as an aside to screening for insecticide, fungicide or herbicide activity) and horticulturists developed field uses for these chemicals is coming to an end.

With the new biochemical techniques available to study molecular genetics, and the increasing availability of mutant genotypes in short cycle model plant systems (Arabidopsis has become the plant biologists' equivalent to Drosophila!), plant physiologists can now focus directly on the relationship between plant hormones and gene expression (see Guiltinan and Deikman, 1994). Already a great deal is known about hormone binding proteins (receptors) and how subsequent signal transduction steps lead to gene expression (see Libbenga and Mennes, 1995).

However, progress may not be as rapid as some might expect. There may be several receptors for a given hormone, each leading to the expression of a different gene. And if we add to this the possibility that more than one hormone may be required for the expression of some genes, one can see that there is still an immense challenge to be addressed. Furthermore, we will still need traditional biochemical and physiological techniques to determine how the products of gene expression (proteins) lead to horticulturally important growth and development phenomena.

Thus, it may be some years before the discoveries coming from this research result in substantially improved plant materials or better PBR tools. When it does happen I suspect that we will see a combination of these two outcomes.

So, "Phase IV," which started under a cloud of public mistrust, has turned into a period of discovery not unlike Phase II. However, instead of discovering the potential of auxin we are exploring the potential of molecular genetics to spawn a host of new technologies for use in horticulture. It seems to me to be a time of "getting ready" for another "Golden Age" of product and technology development.

\section{CONCLUSIONS}

Clearly, research on hormone physiology and/or on synthetic plant bioregulating chemicals continues to be an important theme in horticultural science. This is not surprising given that hundreds of valuable technologies have arisen from this research and those still in use (most are still important somewhere in the world) require some ongoing research.

In the 1940 s and 1950s the new technologies that arose from the discovery of auxin revolutionized many areas of horticulture. Gibberellins (and gibberellin inhibitors) proved in the 1960s and 1970s to be equally useful tools. During this period ethylene generators found a multitude of practical applications in horticulture. In the 1980 s ever more powerful cytokinins were used in tissue culture propagation systems. Their potential to dramatically influence fruit growth, by altering carbohydrate distribution patterns in plants, was demonstrated.

There is reason to believe that the 1990 s will see the commercialization of a powerful ethylene biosynthesis inhibitor, the introduction of a gibberellin analog that actually retards stem elongation, the development of chemicals that reduce water loss and other causes of plant stress, and the appearance of PBRs based on natural products such as brassinosteroid, jasmonic acid and others only recently identified as having PBR activity. The search will intensify for natural product chemicals that function as effectors or messengers in the control of plant growth and development.

Using the tools of the molecular geneticist we will finally answer the nagging questions about how plant hormones actually work at the molecular level. One important outcome of this research will be transformed crop plants that no longer require a particular PBR-based technology to achieve the production efficiency or product quality goals so necessary for commercial success.

However, advances in molecular genetics will also introduce new opportunities for regulating plant growth and development with totally new chemical tools. There can be no doubt that signal transduction and gene expression involve natural chemicals far more diverse than the few standard "hormones" studied to date. The PBR chemicals of the future will most likely arise from natural product chemistry and have very targeted activity exerted within a well-defined time frame. Residues will be minimal or nonexistent and the effects on nontarget organisms will be nil or nonsignificant.

If this scenario plays out as expected it is not unreasonable to suggest that horticulturists, working hand in hand with industry and with scientists in a multitude of other disciplines, may very well continue to ride the "hormones and horticulture band wagon" for another 50 years!

\section{Literature Cited}

Addicot, F.T. and J.L. Lyon. 1969. Physiology of abscisic acid and related substances. Annu. Rev. Plant Physiol. 20:139-164.

Avery, G.S., Jr., and E.B. Johnson, 1947. Hormones and Horticulture: The use of special chemicals in the control of plant growth. McGraw-Hill Book Co., New York and London.

Batjer, L.P. and M.N. Westwood. 1960. 1-naphthyl $N$-methylcarbamate, a new chemical for thinning apples. Proc. Amer. Soc. Hort. Sci. 75:1-4.

Boysen-Jensen, P. 1911. La transmission de l'irritation phototropique dans l'Avena. Bul. Acad. Roy. Danmark 1:3.

Boysen-Jensen, P. 1913. Über die Leitung des phototropischen Reizes in der Avena Koleoptile. Ber. Deutsch. bot. Ges. 31:559-566.

Cooper, W.C. 1935. Hormones in relation to root formation on stem cuttings. Plant Physiol. 10:789-794.

Darwin, C. and F. Darwin. 1980. The power of movement in plants. John Murray, London.

Fitting, H. 1910. Entwicklungsphysiol. Unters. an Orchideenblüten. Zeitschr. für Botanijk. vol. ii.

Gardner, F.E. and P.C. Marth. 1937. Parthenocarpic fruits by spraying. Science 90:208-209. 
Gardner, F.E., P.C. Marth, and L.P. Batjer. 1939. Sprying with plant growth substances to prevent apple fruit dropping. Science 90:208-209

Gardner, F.E., P.C. Marth, and L.P. Batjer. 1940. Spraying with plant growth substances for control of the preharvest drop of apples. Proc. Amer. Soc. Hort. Sci. 37:415-428.

Guiltinan, M.J. and J. Deikman. 1994. Molecular and genetic approaches to the study of plant hormone action. Hort. Rev. 16:1-32.

Gustafson, F.G. 1936. Inducement of fruit development by growth-promoting chemicals. Proc. Natl. Acad. Sci. 22:628-636.

Howlett, F.S. 1940. Experiments concerning the practicability of certain chemicals as a means of inducing fruit setting in the tomato. Proc. Amer. Soc. Hort. Sci. 37:886-890.

Huxley, J.S. 1935. Chemical regulation and the hormone concept. Biol. Rev. Cambridge Philos. Soc. 10:427-441.

LaRue, C.D. 1936. Effect of auxin on abscission of petioles. Proc. Natl. Acad. Sci. 22:254-259.

Letham, D.S. 1967. Chemistry and physiology of kinetin-like compounds. Annu. Rev. Plant Physiol. 18:349-364.

Libbenga, K.R. and A.M. Mennes. 1995. Hormone binding and signal transduction, p. 272-297. In: P.J. Davies (ed.). Plant hormones. Kluwer Academic Publ., Dordrecht.

Miller, C.O., F. Skoog, M.H. Von Saltza, and F.M. Strong. 1955. Kinetin, a cell division factor from deoxyribonucleic acid. J. Amer. Chem. Soc. 77:1392.

Nickell, L.G. 1958. Gibberellin and the growth of plant tissue cultures. Nature 181:499-500.

Ohkuma, K., J.L. Lyon, F.T. Addicot, and O.E. Smith. 1963. Abscisin II, an abscission-accelerating substance from young cotton fruit. Science 142:1592-1593.

Owens, L.D., M. Leiberman, and A. Kunishi. 1971. Inhibition of ethylene production by rhizobitoxine. Plant Physiol. 48:1-4.

Pratt, H.K. and J.D. Goeschl. 1969. Physiological roles of ethylene in plants. Annu. Rev. Plant Physiol. 20:541-584.

Sachs, J. 1880. Stoff und Form der Pflanzenorgani. I. Arb. Bot. Inst. Würzburg 2:452-488.

Schneider, G.W. and J.V. Enzie. 1944. Further studies on the effect of certain chemicals on the fruit set of apple. Proc. Amer. Soc. Hort. Sci. 45:63-68.

Skoog. F. and D.J. Armstrong. 1970. Cytokinins. Annu. Rev. Plant. Physiol. 21:359-384.

Steward.F.C. and N.W. Simmonds. 1954. Growth-promoting substances in the ovary and immature fruit of the banana. Nature 173:1083-1084.

Stowe, B.B. and T. Yamaki. 1957. The history and the physiological action of the gibberellins. Annu. Rev. Plant Physiol. 8:181-216.

Went, F.W. 1928. Wuchstoff und Wachstum. Rec. Trav. Botan. Neerland. 25:1-116.

Went, F.W. 1940. Plant hormones. In: F.R. Moulton (ed.). The cell and protoplasm. AAAS Publ. 14:147-158.

Zimmerman, P.W. and F. Wilcoxon. 1935. Several chemical growth substances which cause initiation of roots and other responses in plants. Contr. Boyce Thompson Inst. 7:209-229.

Zimmerman, P.W. and A.E. Hitchcock. 1942. Substituted phenoxy and benzoic acid growth substances and the relation of structure to physiological activity. Contr. Boyce Thompson Inst. 12: 321-343.

\title{
Hydroponics
}

\author{
Merle H. Jensen \\ Department of Plant Sciences, University of Arizona, Tucson, AZ 85721
}

Hydroponics is a technology for growing plants in nutrient solutions (water containing fertilizers) with or without the use of an artificial medium (sand, gravel, vermiculite, rockwool, perlite, peatmoss, coir, or sawdust) to provide mechanical support. Liquid hydroponic systems have no other supporting medium for the plant roots; aggregate systems have a solid medium of support. Hydroponic systems are further categorized as open (i.e., once the nutrient solution is delivered to the plant roots, it is not reused) or closed (i.e., surplus solution is recovered, replenished, and recycled).

In combination with greenhouses, it is high-technology and capital-intensive. It is also highly productive, conservative of water and land, and protective of the environment. Yet for most of its employees, hydroponic culture requires only basic agriculture skills. Since regulating the aerial and root environment is a major concern in such agricultural systems, production takes place inside enclosures designed to control air and root temperatures, light, water, plant nutrition, and adverse climate.

There are many types of controlled environment/hydroponic systems. Each component of controlled-environment agriculture (CEA) is of equal importance, whether it be the structural design, the environmental control, or the growing system. Not every system is costeffective in every location. All too often, importance is given to only one or two of the key components, but the system fails due to lack of attention to any one of the components. If improper attention is given to the greenhouse structure and its environment, no hydroponic system will prove economically viable. While hydroponic and CEA are not synonymous, CEA usually accompanies hydroponics. Their potentials and problems are inextricable.

Received for publication 4 Mar. 1997. Accepted for publication 4 Apr. 1997. The cost of publishing this paper was defrayed in part by the payment of page charges. Under postal regulations, this paper therefore must be hereby marked advertisement solely to indicate this fact.

\section{HISTORICAL REVIEW}

The development of hydroponics has not been rapid. Although the first use of CEA was the growing of off-season cucumbers under "transparent stone" (mica) for the Roman Emperor Tiberius during the 1st century, the technology is believed to have been used little, if at all, for the following 1500 years.

Greenhouses (and experimental hydroponics) appeared in France and England during the 17th century; Woodward grew mint plants without soil in England in the year 1699. The basic laboratory techniques of nutrient solution culture were developed (independently) by Sachs and Knap in Germany about 1860 (Hoagland and Arnon, 1938).

In the United States, interest began to develop in the possible use of complete nutrient solutions for large-scale crop production about 1925. Greenhouse soils had to be replaced at frequent intervals or else be maintained in good condition from year to year by adding large quantities of commercial fertilizers. As a result of these difficulties, research workers in certain U.S. agricultural experiment stations turned to nutrient solution culture methods as a means of replacing the natural soil system with either an aerated nutrient solution or an artificial soil composed of chemically inert aggregates moistened with nutrient solutions (Withrow and Withrow, 1948).

Between 1925 and 1935, extensive development took place in modifying the methods of the plant physiologists to large-scale crop production. Workers at the New Jersey Agricultural Experiment Station improved the sand culture method (Shive and Robbins, 1937). The water and sand culture methods were used for large-scale production by investigators at the California Agricultural Experiment Station (Hoagland and Arnon, 1938). Each of these two methods involved certain fundamental limitations for commercial crop production, which partially were overcome with the introduction of the subirrigation system initiated in 1934 at the New Jersey and Indiana Agricultural Experiment Stations (Withrow and Withrow, 1948). Gericke (1940) published a description of a quasi-commercial use of the liquid technique and apparently coined the word hydroponics in passing. The 